\title{
Oral health related quality of life and determinant factors in patients with head and neck cancer
}

\author{
Niebla-Bezerra de Melo ${ }^{1}$, Válery-Muniz de Sousa ${ }^{2}$, Ítalo-de Macedo Bernardino ${ }^{1}$, Daniela-Pita de Melo ${ }^{3}$, \\ Daliana-Queiroga-Castro Gomes ${ }^{3}$, Patrícia-Meira Bento ${ }^{3}$
}

${ }^{1}$ Msc. Department of Dentistry, State University of Paraíba, Campina Grande, Brazil
${ }^{2}$ Department of Dentistry, State University of Paraíba, Campina Grande, Brazil
${ }^{3}$ PhD. Department of Dentistry, State University of Paraíba, Campina Grande, Brazil

Correspondence:

Rua Baraúnas 351

Bairro Universitário - Campina Grande

Paraíba, Brazil

Postal code: $58429-500$

patmeira@uol.com

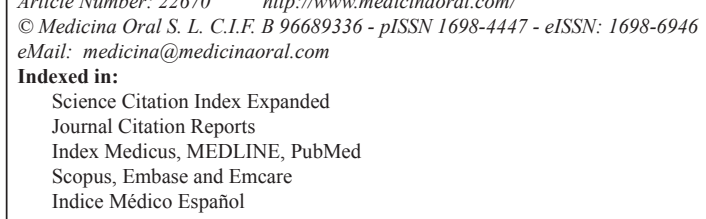

\begin{abstract}
Background: The present study aimed to measure the impact of oral health on the quality of life of patients with head and neck cancer.

Material and Methods: A cross-sectional study was conducted with 130 patients diagnosed with head and neck cancer at two medical centers. Participants answered a sociodemographic questionnaire and the Oral Health Impact Profile - 14 (OHIP-14). Clinical aspects, cancer staging, and treatment approach were also investigated. Mann-Whitney and Kruskal-Wallis non-parametric tests were used for statistical analysis, followed by Poisson regression analysis (with robust error variance), to associate the OHIP-14 scores with independent variables.

Results: The OHIP-14 presented good internal consistency (Cronbach's Alpha $=0.861$ ). The mean score obtained was 19.52 ( \pm 11.79$)$. Physical pain (3.70 \pm 2.44$)$, physical disability (3.26 \pm 2.62$)$ and functional limitation $(3.24 \pm 2.45)$ were ranked as the main factors affecting the quality of life. Patients non-Caucasians ( $\mathrm{PR}=1.30$; IC 95\% $=1.07$ $1.58 ; \mathrm{p}=0.009)$, widowers $(\mathrm{PR}=1.36$; IC $95 \%=1.13-1.64 ; p=0.001)$, diagnosed with squamous cell carcinoma $(\mathrm{PR}=1.28 ; \mathrm{IC} 95 \%=1.05-1.58 ; p=0.017)$ and with temporomandibular pain $(\mathrm{PR}=1.31 ; \mathrm{IC} 95 \%=1.08-1.60 ; p=$ 0.007 ) were more likely to exhibit lower rates of quality of life.

Conclusions: The results showed a high impact of the oral health in the quality of life of patients with head and neck cancer was observed. Sociodemographic and clinical characteristics can exert influence on the quality of life of patients with head and neck cancer.
\end{abstract}

Key words: Quality of life, malignant neoplasms, head and neck neoplasms, oral health, epidemiology. 


\section{Introduction}

Head and neck cancer (HNC) is ranked 6th in a global scale - with an annual incidence ranging from 400.000 to 700.000 new cases $(1,2)$. The oral cavity and the larynx are the most affected regions in the head and neck $(3,4)$. In 2012, 300.400 new cases of cancer in the oral cavity and 156.877 new cases of cancer in the larynx were reported in the world (1).

In most of the cases, head and neck tumors may destroy organs that play an important part in daily activities such as eating and speaking (5). Additionally, the therapeutic approaches for the treatment of cancer usually result in collateral effects $(6,7)$. that impact in the quality of life. The assessment of the quality of life in patients with cancer became a valuable tool to investigate the progression of the disease and the effectiveness of the treatment (8).

The oral condition has an essential role in the individual's systemic health (9). In specific, the quality of liferelated to oral health (OHRQoL) may be defined as the lack of negative impact of the oral condition on social, psychological and functional activities (10). In general, patients with tumors in the oral cavity figure amongst the worst indices for the quality of life when compared to patients with tumors in other regions (11). Based on the exposed, the present study aimed to measure the impact of OHRQoL of patients with HNC and to evaluate the factors associated.

\section{Material and Methods}

-Study design and setting

A cross-sectional study was conducted with 130 patients under treatment for HNC at two medical centers belonging to the Unified Health System (SUS) between November 2016 and April 2017. These institutions are located in Northeastern Brazil and are a reference for about 69 municipalities, covering a population of approximately $1,025,343$ inhabitants. The study region has significant social, economic, and cultural disparities. Patients were selected consecutively since consecutive sampling is typically better than convenience sampling in controlling sampling bias.

All the procedures performed in the present study were approved by the Committee of Ethics in Research of the State University of Paraiba, under the protocol number: CAAE 61101716.9.0000.5187 in accordance with Resolution 466/12 of the National Health Council (CNS) and the Declaration of Helsinki. All the patients were asked to sign informed consents prior to data collection. The STROBE (STrengthening the Reporting of OBservational studies in Epidemiology) checklist was used to assist in conducting the survey.

-Eligibility criteria

The eligibility criteria were: patients diagnosed with $\mathrm{HNC}$ before or during anti-neoplastic treatment (sur- gery/chemotherapy/radiotherapy); patients over 18 years of age and patients with altered cognitive ability. -Training and calibration exercise

Prior to data collection, a pilot study and training and calibration procedures were conducted. Twenty patients were selected to answer the questionnaires. After an interval of 7 days, the questionnaires were applied again to determine the agreement of responses. In this step, the participants did not present difficulties to understand the questions and, therefore, the data collection instruments were not modified. Kappa test values ranged from 0.81 to 0.95 , indicating excellent concordance.

-Non-clinical data collection

The acquisition of nonclinical data involved the administration of a questionnaire containing sociodemographic and economic variables and the Oral Health Impact Profile (OHIP-14) to evaluate the OHRQoL. Sociodemographic variables were categorized as follows: age ( $\leq 39$ years / 40-49 years / 50-59 years / 60-69 years / $70-79$ years $\geq 80$ years), sex (male / female), occupation (retired/farmer/other), self-declared skin color (Caucasian / non-caucasian), marital status (married / single / widowed / divorced), monthly income $(<1$ Brazilian minimum salary / 1- 2 Brazilian minimum salaries / >2 Brazilian minimum salaries).

The OHIP-14 is a validated instrument to assess the impact of oral problems in the quality of life composed of 14 questions that measure individual perception about the biopsychosocial impact of oral disorders associated with quality of life, providing a comprehensive detection of discomfort, disability, and dysfunction attributed to poor oral conditions. High scores indicate a greater impact of oral health on quality of life and, consequently, worse OHRQoL (12-14).

-Clinical data collection

The clinical data collection was conducted in the medical records of each patient. Data were extracted from patient charts and recorded on a specific individual clinical chart for the study addressing anatomic location of the lesion (oral cavity / pharynx / larynx / neck region / other), diagnosis (squamous-cell carcinoma / Metastatic carcinoma / Adenocarcinoma / Non-Hodgkin lymphoma / Hodgkin lymphoma / Osteosarcoma / other), clinical staging (initial - I or II / advanced - III or IV), treatment stage (before / during); chemotherapy (yes / no); radiotherapy (yes / no); last visit to the dentist ( $<6$ months / $1-2$ years / $>2$ years); pain in the TMJ (yes / no); smoker (yes / no); former smoker (yes / no); alcoholic (yes / no); former alcoholic (yes / no).

-Data analysis

Initially, descriptive statistics were performed to screen the general sample characteristics. The qualitative variables were quantified in absolute and relative frequencies, while the quantitative variables underwent 
the quantification of central tendency and variability. Mann-Whitney and Kruskal-Wallis non-parametric tests were used to compare the OHIP-14 scores according to the characteristics of the patients. These tests were performed because data normality and homogeneity were not confirmed after Kolmogorov-Smirnov and Levene's tests, respectively.

Next, Poisson regression analysis (with robust error variance) was performed to associate the dependent variable (OHIP-14 score) with the independent variables (social, demographic and financial information, clinical condition, prognosis, and treatment approach). Variables with a $p$-value $<0.25$ in the univariate analysis were included in the multivariate model. However, in the final model only the variables with a $p$-value $<0.05$ were maintained. The prevalence ratio (PR) was calculated for the univariate analysis, while an adjusted PR was calculated for the multivariate analysis $(15,16)$. All the statistical analyses were performed with SPSS 20.0 software (IBM Corp., Armonk, NY, USA) with statistical significance set at $5 \%(p<0.05)$.

\section{Results}

Table 1, 1 continue, 1 continue-1, expresses the sample distribution based on social, demographic, financial characteristics, the clinical condition of the patient, the prognosis and the treatment approach of the patients. Most of the patients were males $(\mathrm{n}=91 ; 70.0 \%)$ aged between 60 and 69 years old $(n=36 ; 27.7 \%)$ with monthly income between 1 and 2 minimum salaries $(n=92 ; 70.8 \%)$. Most of the patients had cancer in the oral cavity $(23.8 \%)$ or larynx (23.8\%). Most of the cancer lesions were diagnosed as squamous cell carcinoma (66.2\%) in advanced stage (72.1\%) i.e., in stage III or IV of the TNM classification of malignant tumors. Reports of pain in the teeth and in the temporomandibular joint reached $16.9 \%$ and $36.2 \%$, respectively. Former smokers and alcoholics accounted for $65.4 \%$ and $67.7 \%$ of the patients.

Table 1: Sample distribution based on social, demographic, financial conditions clinical condition, prognosis and treatment approach.

\begin{tabular}{|l|c|c|}
\hline Variables & $\mathbf{n}$ & $\mathbf{\%}$ \\
\hline Age range $[\mathbf{n}=\mathbf{1 3 0}]$ & & \\
\hline$\leq 39$ years & 13 & 10.0 \\
\hline $40-49$ years & 18 & 13.8 \\
\hline 50-59 years & 29 & 22.3 \\
\hline $60-69$ years & 36 & 27.7 \\
\hline $70-79$ years & 21 & 16.2 \\
\hline$\geq 80$ years & 13 & 10.0 \\
\hline Sex $[\mathbf{n}=\mathbf{1 3 0}]$ & & \\
\hline Males & 91 & 70.0 \\
\hline Females & 39 & 30.0 \\
\hline
\end{tabular}

Table 1 continue: Sample distribution based on social, demographic, financial conditions clinical condition, prognosis and treatment approach.

\begin{tabular}{|c|c|c|}
\hline \multicolumn{3}{|l|}{ Occupation $[n=130]$} \\
\hline Retired & 30 & 23.1 \\
\hline Farmer & 39 & 30.0 \\
\hline Other & 61 & 46.9 \\
\hline \multicolumn{3}{|l|}{$\begin{array}{l}\text { Self-declared skin color } \\
{[n=130]}\end{array}$} \\
\hline Caucasian & 64 & 49.2 \\
\hline Non-caucasian & 66 & 50.8 \\
\hline \multicolumn{3}{|l|}{ Marital status [n=130] } \\
\hline Married & 77 & 59.2 \\
\hline Single & 26 & 20.0 \\
\hline Widower & 13 & 10.0 \\
\hline Divorced & 14 & 10.8 \\
\hline \multicolumn{3}{|l|}{ Monthly income [n=130] } \\
\hline$<1$ minimum salary & 22 & 16.9 \\
\hline $\begin{array}{l}\text { Between } 1 \text { and } 2 \text { minimum } \\
\text { salaries }\end{array}$ & 92 & 70.8 \\
\hline$>2$ minimum salaries* & 16 & 12.3 \\
\hline \multicolumn{3}{|l|}{$\begin{array}{l}\text { Anatomic location of the } \\
\text { lesion }[n=130]\end{array}$} \\
\hline Oral cavity & 31 & 23.8 \\
\hline Pharynx & 21 & 16.2 \\
\hline Larynx & 31 & 23.8 \\
\hline Cervical region & 19 & 14.6 \\
\hline Other & 28 & 21.5 \\
\hline \multicolumn{3}{|l|}{ Diagnosis $[n=130]$} \\
\hline Squamous cell carcinoma & 86 & 66.2 \\
\hline Metastatic carcinoma & 11 & 14.3 \\
\hline Adenocarcinoma & 2 & 2.6 \\
\hline Non- Hodgkin lymphoma & 5 & 6.5 \\
\hline Hodgkin lymphoma & 3 & 3.9 \\
\hline Osteosarcoma & 2 & 2.6 \\
\hline Other & 13 & 16.9 \\
\hline \multicolumn{3}{|l|}{ Clinical staging $[n=86]$} \\
\hline Inicial stage (I or II) & 24 & 27.9 \\
\hline Advanced stage (III or IV) & 62 & 72.1 \\
\hline \multicolumn{3}{|l|}{ Treatment stage $[\mathrm{n}=130]$} \\
\hline Before & 28 & 21.5 \\
\hline During & 102 & 78.5 \\
\hline \multicolumn{3}{|l|}{ Surgery $[\mathrm{n}=130]$} \\
\hline Yes & 50 & 38.5 \\
\hline No & 80 & 61.5 \\
\hline \multicolumn{3}{|l|}{ Chemotherapy [n=130] } \\
\hline Yes & 66 & 50.8 \\
\hline No & 64 & 49.2 \\
\hline \multicolumn{3}{|l|}{ Radiotherapy [n=130] } \\
\hline Yes & 70 & 53.8 \\
\hline No & 60 & 46.2 \\
\hline
\end{tabular}


Table 1 continue-1: Sample distribution based on social, demographic, financial conditions clinical condition, prognosis and treatment approach.

\begin{tabular}{|l|c|c|}
\hline $\begin{array}{l}\text { Last visit to the dentist } \\
\text { [n=130] }\end{array}$ & & \\
\hline$<6$ months & 69 & 53.1 \\
\hline Between 1 and 2 years & 14 & 10.8 \\
\hline$>2$ years & 47 & 36.2 \\
\hline Pain in the TMJ [n=130] & & \\
\hline Yes & 47 & 36.2 \\
\hline No & 83 & 63.8 \\
\hline Smoker [n=130] & 10 & 7.7 \\
\hline Yes & 120 & 92.3 \\
\hline No & & 67.7 \\
\hline Former smoker $[\mathbf{n = 1 3 0 ]}$ & 85 & 65.4 \\
\hline Yes & 45 & 34.6 \\
\hline No & 10 & \\
\hline Alcoholic [n=130] & & 7.7 \\
\hline Yes & & \\
\hline No & & \\
\hline Former alcoholic $[\mathbf{n}=\mathbf{1 3 0}]$ & & \\
\hline Yes & & \\
\hline No & & \\
\hline
\end{tabular}

Note. [n]: number of patients that replied to the question; $\mathrm{n}$ : absolute number of patients; \%: relative number of patients; *Minimum salary: R\$ 937.00 ( $\approx$ US\$ 282,82); TMJ: temporomandibular joint.

OHIP-14 had good internal consistency (Cronbach's Alpha $=0.861)$. Table 2 shows the quantification of central tendency and variability of the OHIP-14 scores. The mean score was $19.52( \pm 11.79)$. Pain $(3.70 \pm 2.44)$, physical disability (3.26 \pm 2.62$)$ and functional limitation $(3.24 \pm 2.45)$ were ranked as the main factors affecting the quality of life.

Table 3, 3 continue, 3 continue- 1 expresses the outcomes of the comparative analysis of OHIP-14 scores based on the clinical condition of the patient, the prognosis and the treatment approach. Differences statistically significant were observed for the following variables: self-declared skin color $(p<0.05)$, anatomic location of the lesion $(p<0.05)$, dental pain $(p<0.05)$ pain in the temporomandibular joint $(p<0.05)$.

Table 4, 4 continue expresses the outcomes of Poisson regression analysis based on the OHIP-14 total scores and the variables investigated. Considering the final multivariate model, the factors associated with the decrease in the quality of life were the self-declared skin color $(p<0.05)$, marital status $(p<0.05)$, diagnosis of the lesion $(p<0.05)$ and pain in the temporomandibular joint $(p<0.05)$. Non-Caucasians $(\mathrm{PR}=1.30$; IC 95\% $=1.07-1.58 ; p=0.009)$, widowers $(\mathrm{PR}=1.36$; IC 95\% $=1.13-1.64 ; p=0.001)$, patients diagnosed with squamous cell carcinoma $(\mathrm{PR}=1.28$; IC 95\% $=1.05-1.58 ; p$ $=0.017)$ and patients with pain the temporomandibular joint $(\mathrm{PR}=1.31$; IC 95\% $=1.08-1.60 ; p=0.007) \mathrm{had}$ more propensity to reach higher scores in the OHIP-14 - indicating potential impact in the quality of life.

\section{Discussion}

Malignant neoplasms of the head and neck affect more often male subjects aged above 40 years of age. Nearly $90 \%$ of these tumors are diagnosed as squamous cell carcinoma. In most of the cases, the malignant lesions are detected in an advanced stage (stages III and IV) (17-19) in the oral cavity, the larynx and the pharynx $(18,20)$. These findings were also observed in the sample investigated in the present study. Furthermore, the found prevalence of former smokers and alcoholics, as well as patients that work in the countryside highlights some of the risk factors for HNC (19-21).

In relation to the oral health habits, the patients of the present study reported the previous consultation with a dentist before the antineoplastic treatment. This finding may be justified by the dental services offered by both hospitals visited during the study. However, it is important to note that a large part of the sample reported the previous consultation with a dentist dated more than 2 years ago.

Table 2: Measurements of central tendency and variability of the scores obtained with the OHIP-14 index.

\begin{tabular}{|l|c|c|c|c|c|}
\hline OHIP-14 variables & Mean & Median & SD & Min. & Max. \\
\hline 1. Functional limitation & 3.24 & 3.00 & 2.45 & 0.00 & 8.00 \\
\hline 2. Physical pain & 3.70 & 4.00 & 2.44 & 0.00 & 8.00 \\
\hline 3. Psychological discomfort & 2.76 & 3.00 & 2.54 & 0.00 & 8.00 \\
\hline 4. Physical disability & 3.26 & 3.00 & 2.62 & 0.00 & 8.00 \\
\hline 5. Psychological disability & 1.79 & 2.00 & 2.12 & 0.00 & 8.00 \\
\hline 6. Social disability & 1.96 & 2.00 & 2.06 & 0.00 & 8.00 \\
\hline 7. Deficiency & 2.80 & 2.50 & 2.58 & 0.00 & 8.00 \\
\hline Total score & 19.52 & 18.00 & 11.79 & 0.00 & 51.00 \\
\hline
\end{tabular}

Note. OHIP-14: Oral Health Impact Profile-14; SD: standard deviation; min.: minimum value; max.: maximum value. 
Table 3: Comparative analysis between the OHIP-14 scores and the social, demographic, financial and clinical conditions, as well prognosis and treatment approach.

\begin{tabular}{|c|c|}
\hline \multirow[t]{2}{*}{ Variables } & OHIP-14 score \\
\hline & Mean (SD) \\
\hline \multicolumn{2}{|l|}{ Age range } \\
\hline$\leq 39$ years & $15.15(11.74)$ \\
\hline $40-49$ years & $18.83(11.43)$ \\
\hline $50-59$ years & $18.62(10.70)$ \\
\hline $60-69$ years & $21.06(13.28)$ \\
\hline $70-79$ years & $20.76(13.50)$ \\
\hline$\geq 80$ years & $20.54(7.26)$ \\
\hline$p$-value ${ }^{(a)}$ & 0.733 \\
\hline \multicolumn{2}{|l|}{ Sex } \\
\hline Male & $20.80(12.08)$ \\
\hline Female & $16.51(10.65)$ \\
\hline$p$-value ${ }^{\mathrm{b})}$ & 0.091 \\
\hline \multicolumn{2}{|l|}{ Occupation } \\
\hline Retired & $21.93(11.97)$ \\
\hline Farmer & $19.97(12.76)$ \\
\hline Other & $18.03(11.02)$ \\
\hline$p$-value ${ }^{(a)}$ & 0.355 \\
\hline \multicolumn{2}{|l|}{ Self-declared skin color } \\
\hline Caucasian & $16.63(10.19)$ \\
\hline Non-Caucasian & $22.32(12.62)$ \\
\hline$p$-value ${ }^{(\mathrm{b})}$ & $0.012^{*}$ \\
\hline \multicolumn{2}{|l|}{ Marital status } \\
\hline Married & $18.95(11.57)$ \\
\hline Single & $18.38(10.95)$ \\
\hline Widower & $25.62(11.48)$ \\
\hline Divorced & $19.07(14.27)$ \\
\hline$p$-value ${ }^{(a)}$ & 0.311 \\
\hline \multicolumn{2}{|l|}{ Monthly income } \\
\hline$<1$ minimum salary & $20.77(12.82)$ \\
\hline $\begin{array}{l}\text { Between } 1 \text { and } 2 \text { minimum sa- } \\
\text { laries }\end{array}$ & $19.67(11.78)$ \\
\hline$>2$ minimum salaries & $16.88(10.73)$ \\
\hline$p$-value ${ }^{(a)}$ & 0.674 \\
\hline \multicolumn{2}{|l|}{ Anatomic location of the lesion } \\
\hline Oral cavity & $22.10(10.47)$ \\
\hline Pharynx & $25.14(11.08)$ \\
\hline Oral cavity & $17.94(11.78)$ \\
\hline Pharynx & $15.32(12.32)$ \\
\hline Larynx & $17.04(11.93)$ \\
\hline Cervical region & $0.023^{*}$ \\
\hline \multicolumn{2}{|l|}{ Other } \\
\hline Diagnosis $[n=130]$ & $20.78(11.63)$ \\
\hline Squamous cell carcinoma & $17.05(11.86)$ \\
\hline Metastatic carcinoma & 0.073 \\
\hline
\end{tabular}

Table 3 continue: Comparative analysis between the OHIP-14 scores and the social, demographic, financial and clinical conditions, as well prognosis and treatment approach.

\begin{tabular}{|c|c|}
\hline \multicolumn{2}{|l|}{ Adenocarcinoma } \\
\hline Non-Hodgkin lymphoma & $17.50(7.83)$ \\
\hline Hodgkin lymphoma & $22.00(12.70)$ \\
\hline Osteosarcoma & 0.182 \\
\hline \multicolumn{2}{|l|}{ Other } \\
\hline Clinical staging $[n=86]$ & $19.04(14.35)$ \\
\hline Inicial stage (I or II) & $19.65(11.07)$ \\
\hline Advanced stage (III or IV) & 0.598 \\
\hline \multicolumn{2}{|l|}{ Treatment stage $[\mathrm{n}=130]$} \\
\hline Before & $17.36(9.71)$ \\
\hline During & $20.86(12.80)$ \\
\hline Surgery $[\mathrm{n}=130]$ & 0.133 \\
\hline \multicolumn{2}{|l|}{ Yes } \\
\hline No & $20.80(11.18)$ \\
\hline Chemotherapy [n=130] & $18.19(12.34)$ \\
\hline Yes & 0.155 \\
\hline \multicolumn{2}{|l|}{ No } \\
\hline Radiotherapy [n=130] & $20.83(10.70)$ \\
\hline Yes & $17.98(12.87)$ \\
\hline No & 0.105 \\
\hline \multicolumn{2}{|c|}{ Last visit to the dentist $[n=130]$} \\
\hline$<6$ months & $20.26(10.26)$ \\
\hline Between 1 and 2 years & $15.43(13.15)$ \\
\hline$>2$ years & $19.64(13.41)$ \\
\hline p-value ${ }^{(a)}$ & 0.107 \\
\hline \multicolumn{2}{|l|}{ Dental pain } \\
\hline Yes & $24.27(11.66)$ \\
\hline No & $18.55(11.64)$ \\
\hline p-value ${ }^{(b)}$ & $0.030^{*}$ \\
\hline \multicolumn{2}{|l|}{ Pain in the TMJ } \\
\hline Yes & $23.43(13.32)$ \\
\hline No & $17.30(10.27)$ \\
\hline$p$-value ${ }^{(\mathrm{b})}$ & $0.009 *$ \\
\hline \multicolumn{2}{|l|}{ Smoker } \\
\hline Yes & $24.80(14.88)$ \\
\hline No & $19.08(11.47)$ \\
\hline$p$-value ${ }^{(\mathrm{b})}$ & 0.319 \\
\hline \multicolumn{2}{|l|}{ Former smoker } \\
\hline Yes & $20.45(11.36)$ \\
\hline No & $17.76(12.52)$ \\
\hline$p$-value ${ }^{(b)}$ & 0.160 \\
\hline \multicolumn{2}{|l|}{ Alcoholic } \\
\hline Yes & $16.80(15.86)$ \\
\hline No & $19.74(11.45)$ \\
\hline$p$-value ${ }^{(\mathrm{b})}$ & 0.336 \\
\hline
\end{tabular}


Table 3 continue-1: Comparative analysis between the OHIP-14 scores and the social, demographic, financial and clinical conditions, as well prognosis and treatment approach.

\begin{tabular}{|l|c|}
\hline Former alcoholic & \\
\hline Yes & $20.85(11.38)$ \\
\hline No & $16.71(12.29)$ \\
\hline$p$-value $^{(b)}$ & 0.054 \\
\hline
\end{tabular}

Note. SD: standard deviation; TMJ: temporomandibular joint; ${ }^{(a)}$ Teste de Kruskal-Wallis; (b) Teste de Mann-Whitney; ${ }^{*} p<0.05$.
In the present study, the OHIP-14 reached good internal consistency. The OHIP-14 pointed towards a high impact in the quality of life of the patients sampled. Patients with HNC experience reported a statistically superior impact on quality of life when compared to cancer-free individuals (22). In the present study, the main complaints reported by the patients were the physical pain, physical disability, and functional limitation. These outcomes corroborate with Barrios et al. (2015)

Table 4: Poisson regression analysis for the OHIP-14 score based on the social, demographic, financial and clinical conditions, as well prognosis and treatment approach.

\begin{tabular}{|c|c|c|c|c|}
\hline \multirow[t]{2}{*}{ Variables } & \multicolumn{2}{|c|}{ Univariate analysis } & \multicolumn{2}{|c|}{ Multivariate analysis } \\
\hline & $\begin{array}{l}\text { PR }_{\text {Non adjusted }} \\
\text { (IC 95\%) }\end{array}$ & $p$-value & $\begin{array}{l}\text { PR } \\
\text { (IC 95\%) }\end{array}$ & $p$-value \\
\hline \multicolumn{5}{|l|}{ Age range } \\
\hline$\leq 39$ years & 1 & & - & - \\
\hline 40-49 years & $1.24(0.76-2.02)$ & 0.382 & - & - \\
\hline $50-59$ years & $1.23(0.78-1.93)$ & 0.374 & - & - \\
\hline $60-69$ years & $1.39(0.88-2.19)$ & 0.154 & - & - \\
\hline $70-79$ years & $1.37(0.84-2.23)$ & 0.205 & - & - \\
\hline$\geq 80$ years & $1.36(0.87-2.11)$ & 0.180 & - & - \\
\hline \multicolumn{5}{|l|}{ Sex } \\
\hline Male & $1.26(1.00-1.59)$ & 0.052 & - & - \\
\hline Female & 1.00 & & - & - \\
\hline \multicolumn{5}{|l|}{ Occupation } \\
\hline Retired & $1.22(0.95-1.55)$ & 0.117 & - & - \\
\hline Farmer & $1.11(0.86-1.42)$ & 0.422 & - & - \\
\hline Other & 1.00 & & - & - \\
\hline \multicolumn{5}{|l|}{ Self-declared skin color } \\
\hline Caucasian & 1.00 & & 1.00 & \\
\hline Non-Caucasian & $1.34(1.10-1.64)$ & $0.004 *$ & $1.30(1.07-1.58)$ & $0.009 *$ \\
\hline \multicolumn{5}{|l|}{ Marital status } \\
\hline Married & 1.00 & & 1.00 & \\
\hline Single & $0.97(0.75-1.26)$ & 0.822 & $0.97(0.76-1.25)$ & 0.838 \\
\hline Widower & $1.35(1.03-1.77)$ & $0.029 *$ & $1.36(1.13-1.64)$ & $0.001^{*}$ \\
\hline Divorced & $1.01(0.67-1.50)$ & 0.975 & $1.08(0.76-1.55)$ & 0.659 \\
\hline \multicolumn{5}{|l|}{ Monthly income } \\
\hline$<1$ minimum salary & $1.23(0.83-1.82)$ & 0.300 & - & - \\
\hline $\begin{array}{l}\text { Between } 1 \text { and } 2 \\
\text { minimum salaries }\end{array}$ & $1.17(0.84-1.61)$ & 0.355 & - & - \\
\hline$>2$ minimum salaries & 1.00 & & - & - \\
\hline \multicolumn{5}{|c|}{$\begin{array}{l}\text { Anatomic location of the } \\
\text { lesion }\end{array}$} \\
\hline Oral cavity & $1.30(0.96-1.76)$ & 0.093 & - & - \\
\hline Pharynx & $1.48(1.08-2.02)$ & $0.015^{*}$ & - & - \\
\hline Larynx & $1.05(0.75-1.48)$ & 0.768 & - & - \\
\hline Cervical region & $0.90(0.58-1.39)$ & 0.631 & - & - \\
\hline Other & 1.00 & & - & - \\
\hline
\end{tabular}


Table 4 continue: Poisson regression analysis for the OHIP-14 score based on the social, demographic, financial and clinical conditions, as well prognosis and treatment approach.

\begin{tabular}{|c|c|c|c|c|}
\hline Diagnosis & & & & \\
\hline Squamous cell carcinoma & $1.22(0.96-1.54)$ & 0.098 & $1.28(1.05-1.58)$ & $0.017^{*}$ \\
\hline Outher & 1.00 & & 1.00 & \\
\hline \multicolumn{5}{|l|}{ Clinical staging } \\
\hline Initial (I or II) & 1.00 & & - & - \\
\hline Advanced (III or IV) & $1.26(1.01-1.58)$ & $0.047 *$ & - & - \\
\hline \multicolumn{5}{|l|}{ Treatment stage } \\
\hline Before & 1.00 & & - & - \\
\hline During & $1.03(0.77-1.39)$ & 0.834 & - & - \\
\hline \multicolumn{5}{|l|}{ Surgery } \\
\hline Yes & 1.00 & & - & - \\
\hline No & $1.20(0.98-1.47)$ & 0.077 & - & - \\
\hline \multicolumn{5}{|l|}{ Chemotherapy } \\
\hline Yes & $1.14(0.93-1.41)$ & 0.208 & - & - \\
\hline No & 1.00 & & - & - \\
\hline \multicolumn{5}{|l|}{ Radiotherapy } \\
\hline Yes & $1.16(0.93-1.44)$ & 0.182 & - & - \\
\hline No & 1.00 & & - & - \\
\hline \multicolumn{5}{|l|}{ Last visit to the dentist } \\
\hline$<6$ months & $1.03(0.82-1.29)$ & 0.787 & - & - \\
\hline Between 1 and 2 years & $0.79(0.49-1.26)$ & 0.316 & - & - \\
\hline$>2$ years & 1.00 & & - & - \\
\hline \multicolumn{5}{|l|}{ Dental pain } \\
\hline Yes & $1.31(1.04-1.65)$ & $0.021^{*}$ & - & - \\
\hline No & 1.00 & & - & - \\
\hline \multicolumn{5}{|l|}{ Pain in the TMJ } \\
\hline Yes & $1.35(1.10-1.66)$ & $0.004 *$ & $1.31(1.08-1.60)$ & $0.007 *$ \\
\hline No & 1.00 & & 1.00 & \\
\hline \multicolumn{5}{|l|}{ Smoker } \\
\hline Yes & $1.30(0.90-1.88)$ & 0.163 & - & - \\
\hline No & 1.00 & & - & - \\
\hline \multicolumn{5}{|l|}{ Former smoker } \\
\hline Yes & $1.15(0.91-1.46)$ & 0.239 & - & - \\
\hline No & 1.00 & & - & - \\
\hline \multicolumn{5}{|l|}{ Alcoholic } \\
\hline Yes & $0.85(0.48-1.50)$ & 0.575 & - & - \\
\hline No & 1.00 & & - & - \\
\hline \multicolumn{5}{|l|}{ Former alcoholic } \\
\hline Yes & $1.25(0.97-1.60)$ & 0.080 & - & - \\
\hline No & 1.00 & & - & - \\
\hline
\end{tabular}

Note. TMJ: temporomandibular joint; PR: prevalence ratio; IC: confidence interval; * $p<0.05$.

(23) and Stuani et al. (2018) (22). Head and neck tumors can destroy the integrity of surrounding organs that are crucial to essential human functions leading to profound physical changes (24).
Patients self-declared non-Caucasians, widowers and diagnosed with squamous cell carcinoma and with pain in the temporomandibular joint had more propensity to reach higher scores in the OHIP-14 in this study. There 
is no consensus in the scientific literature on the influence of skin color in the quality of life, however, this result can be explained by socioeconomic factors $(25,26)$. Marital support has an essential part in the improvement of the clinical condition in patients with cancer (27). In this context, patients that lost their partner may experiment higher negative impact in their quality of life - especially when affected by a disease. Additionally, patients diagnosed with squamous cell carcinoma expressed through the OHIP-14 scale a high impact in their quality of life. It highlights and confirms a decrease in their quality of life-related to oral health (28). In relation to the temporomandibular joint, the local expansion of the head and neck tumor itself (or its metastasis) together with the antineoplastic treatment may damage adjacent structures in the maxillofacial complex, such as muscles, neural bundles, supporting tissues and the temporomandibular joint (29). Consequently, the complaint of pain is reported expressing a negative impact on the quality of life.

Measuring the quality of life of patients in relation to their health condition became more important over time (18). This procedure may be used as an indicator of the effectiveness of the treatment and the specific areas in which the patient needs more attention (30). For that reason, the patient must be examined in total with special attention to oral health, which has an important role in the quality of life of patients with HNC (10).

This study has some limitations. Due to the cross-sectional design, it is not possible to establish causal relations. In addition, responses in the questionnaires may have been subject to information bias. However, a number of measures were taken to lessen the occurrence of such bias, such as using a validated questionnaire and conducting a pilot study. Besides that, a wide variety of histological types of tumors were observed in the study. However, the majority of the sample had tumors in similar clinical staging (advanced stage), allowing the comparison between them.

On the other hand, the present study contributed to the advancement of scientific knowledge for three main reasons. First, it evaluated the OHRQoL in patients with head and neck cancer. Second, it allowed identifying determinants factors of OHRQoL. Third, the results of this study may help in the implementation of public health policies.

\section{Conclusions}

A high impact on the quality of life-related to oral health was observed in the present study. Self-declared skin color, marital status, diagnosis and pain in the TMJ were factors associated with the OHRQoL. More specific patients self-declared non-Caucasians, widowers, and those diagnosed with squamous cell carcinoma and temporomandibular pain hade more propensity for higher scores in the OHIP-14 - indicating potential impact in the quality of life.

\section{References}

1. Ferlay J, Soerjomataram I, Ervik M, Dikshit R, Eser S, Mathers $\mathrm{C}$, et al. Cancer Incidence and Mortality Worldwide: IARC Cancer Base. Lyon, France: International Agency for Research on Cancer. GLOBOCAN 2012 (1.0), 2013.

2. Torre LA, Bray F, Siegel RL, Ferlay J, Lortet-Tieulent J, Jemal A. Global cancer statistics 2012. CA Cancer J Clin. 2015;65:87-108.

3. LeHew Charles W, et al. The health system and policy implications of changing epidemiology for oral cavity and oropharyngeal cancers in the United States from 1995 to 2016. Epidemiologic Reviews. 2017;39:132-47.

4. Dhanuthai K, Rojanawatsirivej S, Thosaporn W, Kintarak S, Subarnbhesaj, A, Darling M, et al. Oral cancer: A multicenter study. Med Oral Patol Oral Cir Bucal. 2018;23:23-9.

5. Shavi GR, Thakur B, Bhambal A, Jain S, Singh V, Shukla A. Oral health related quality of life in patients of head and neck cancer attending cancer Hospital of Bhopal City, India. J Int Oral Health. 2015;7:21-7.

6. Felippu AWD, Freire EC, Silva RA, Guimarães AV, Dedivitis RA. Impacto da demora no diagnóstico e tratamento no câncer de cabeça e pescoço. Braz. j. otorhinolaryngol. 2016;82:140-3.

7. Angadi V, Dressler E, Stemple J, Multidimensional Study of Vocal Function Following Radiation Therapy for Laryngeal Cancers. Annals of Otology, Rhinology \& Laryngology. 2017;126:483-2.

8. Barkokebas A, Silva IH, de Andrade SC, Carvalho AA, Gueiros LA, et al. J Oral Pathol Med. 2015;44:746-751.

9. Santos PS, Cremonesi AL, Quispe RA, Rubira CM. The impact of oral health on quality of life in individuals with head and neck cancer after radiotherapy: the importance of dentistry in psychosocial issues. Acta Odontol Latinoam. 2017;30:62-7.

10. Mello dos Santos C, Hugo FN, Leal AF, Hilgert JB. Comparison of two assessment instruments of quality of life in older adults. Rev. bras. Epidemiol. 2013;16:328337.

11. Schweyen R, Kuhnt T, Wienke A, Eckert A, Hey J. The impact of oral rehabilitation on oral health-related quality of life in patients receiving radiotherapy for the treatment of head and neck cancer. Clin Oral Invest. 2017;21:1123.

12. Alvarenga FAS, Henriques C, Takatsui F, Montandon AAB, TElarolli JR, et al. Oral health impact profile in the quality of life of patients over 50 years old of two public institutions of Araraquara city, SP, Brazil. Rev Odontol UNESP. 2011;40:118-24.

13. Santos, C. M., Celeste, R.K, Hilgert, J.B., Hugo, F.N. Testing the applicability of a model of oral health-related quality of life. Cad. Saúde Pública, 2015;31:1871-80.

14. Silva AE, Demarco FF, Feldens CA. Oral health-related quality of life and associated factors in Southern Brazilian elderly. Gerodontology. 2015;32:35-45.

15. Coutinho LM, Scazufca M, Menezes PR. Methods for estimating prevalence ratios in cross-sectional studies. Rev Saude Publica. 2008;42:992-8.

16. Hair JF, Black WC, Babin JB, Anderson RE, Tatham RL. Multivariate Data Analysis. 7th ed. Prentice-Hall: Copyright, 2009. 17. Dholam KP, Dugad JA, Sadashiva KM. Impact of oral rehabilitation on patients with head and neck cancer: A study using the Liverpool Oral Rehabilitation Questionnaire and the Oral Health Impact Profile-14. J Prosthet Dent. 2017;117:559-562.

18. Dzebo S, Mahmutovic J, Erkocevic H. Quality of Life of Patients with Oral Cavity Cancer. Materia Socio-Medica. 2017;29:30-34.

19. Dhull AK, Atri R, Dhankhar R, Chauhan A, Kaushal V. Major Risk Factors in Head and Neck Cancer: A Retrospective Analysis of 12-Year Experiences. World J Oncol. 2018; 9(3):80-84.

20. INCA, Instituto Nacional de Câncer José Alencar Gomes da Silva. Coordenação de Prevenção e Vigilância Estimativa 2016: incidência de câncer no Brasil. Instituto Nacional de Câncer José Alencar Gomes da Silva. 2015;122. 
21. Bezerra NVF, Leite KLF, de Medeiros MMD, Martins ML, Cardoso AMR, Alves PM, et al. Impact of the anatomical location, alcoholism and smoking on the prevalence of advanced oral cancer in Brazil. Med Oral Patol Oral Cir Bucal. 2018;23:295-301.

22. Stuani VT, Santos PSS, Damante CA, Zangrando MSR, Greghi SLA, Rezende MLR, et al. Oral health impact profile of head and neck cancer patients after or before oncologic treatment: an observational analytic case-control study. Support Care Cancer. 2018;26:2185-9.

23. Barrios R, Bravo M, Gil-Montoya JA, Martínez-Lara I, GarcíaMedina B, Tsakos G. Oral and general health-related quality of life in patients treated for oral cancer compared to control group. Health and Quality of Life Outcomes. 2015;13:9.

24. Doss JG, Ghani WMN, Razak IA, Yang YH, Rogers SN, Zain, RB. Changes in health-related quality of life of oral cancer patients treated with curative intent: experience of a developing country. Int J Oral Maxillofac. Surg 2017;46:687-98.

25. Zhu J, Xiao Y, Liu F, Wang J, Yang W, Xie W. Measures of healthrelated quality of life and socio-cultural aspects in young patients who after mandible primary reconstruction with free fibula flap. World Journal of Surgical Oncology. 2013;11:250.

26. Siegel R, Ward E, Brawley O, Jemal, A. Cancer statistics, 2011: the impact of eliminating socioeconomic and racial disparities on premature cancer deaths. CA: A Cancer Journal for Clinicians. 2011;61:212-36.

27. Xiao S, Ting-ting Z., Wei-ping H, Qing-hai J. Marital status and survival of patients with oral cavity squamous cell carcinoma: a population-based study. Oncotarget, 2017;8:28526-43.

28. Karbach J, Al-Nawas B, Moergel M, Daubländer M. Oral healthrelated quality of life of patients with oral lichen planus, oral leukoplakia, or oral squamous cell carcinoma. J Oral Maxillofac Surg. 2014;72:1517-22.

29. Stubblefield MD, Manfield L, Riedel ER. A preliminary report on the efficacy of a dynamic jaw opening device (dynasplint trismus system) as part of the multimodal treatment of trismus in patients with head and neck cancer. Arch Phys Med Rehabil. 2010;91:127882 .

30. Hassanein KA, Musgrove BT, Bradbury E. Psychological outcome of patients following treatment of oral cancer and its relation with functional status and coping mechanisms. J Craniomaxillofac Surg, 2005;33:404-9.

\section{Conflicts of Interest}

The authors have declared that no conflict of interest exist. 